\title{
Increased eligibility for treatment of chronic hepatitis C infection with shortened duration of therapy: Implications for access to care and elimination strategies in Canada
}

\author{
Sergio M Borgia MD MSc ${ }^{1,2}$, Adenike Rowaiye MBA MSc ${ }^{1}$
}

\begin{abstract}
SM Borgia, A Rowaiye. Increased eligibility for treatment of chronic hepatitis $\mathrm{C}$ infection with shortened duration of therapy: Implications for access to care and elimination strategies in Canada. Can J Gastroenterol Hepatol 2015;29(3):125-129.
\end{abstract}

BACKGROUND: All oral, highly effective direct-acting antiviral combinations, such as sofosbuvir-ledipasvir, have recently been licensed in Canada but cost as much as $\$ 67,000$ for a 12 -week course of therapy, representing a major economic barrier to predominately single-payer health care systems such as that found in Ontario. In hepatitis $\mathrm{C}$ virus ( $\mathrm{HCV}$ ) genotype 1 noncirrhotic patients with a baseline viral load of $<6 \times 10^{6} \mathrm{IU} / \mathrm{mL}$, treatment with sofosbuvirledipasvir can be shortened to eight weeks without compromising $\geq 95 \%$ efficacy. The number of HCV-infected patients in Ontario eligible for shortened therapy, and the associated cost savings, are unknown. The authors propose that treating every patient with shortened therapy, regardless of baseline viral load, would lead to significant public cost savings and collateral efficiencies, enabling increased HCV treatment capacity and cure.

METHODS: The present study designed a three-part model to investigate the cost of cure per patient and cost savings per patient under three eligibility pathways: conservative, permissive and ideal. In the conservative model, every patient is treated for 12 weeks regardless of baseline viral load, whereas in the permissive model, patients with a baseline viral load $<6 \times 10^{6} \mathrm{IU} / \mathrm{mL}$ are treated for eight weeks. In the ideal model, every patient receives eight weeks of therapy regardless of baseline viral load. Relapsed patients are retreated for 12 weeks. Data obtained from the Ontario Public Health Laboratory were used to validate the model and generate the outcomes.

RESULTS: In Ontario, 75.34\% of HCV genotype 1 patients had a baseline viral load of $<6 \times 10^{6} \mathrm{IU} / \mathrm{mL}$ and were eligible for shortened therapy. The cost of cure per patient in the ideal model was $\$ 47,328.44$, representing a $29 \%$ reduction in the cost of curative therapy and 3.5 weeks of shortened treatment duration compared with the conservative model. The ideal model generated a cost savings per patient of $\$ 3,855.17$ ( $8 \%$ reduction in treatment cost) and 0.7 weeks of shorter therapy compared with the permissive model, and was the shortest and most efficient while maintaining a cure rate $\geq 95 \%$.

CONCLUSIONS: These results demonstrate that recommendations for a shortened treatment course of eight weeks using all-oral direct-acting antivirals in HCV genotype 1 noncirrhotic patients, regardless of baseline viral load, affords significant public cost savings and, on a population level, offers opportunities for expanded HCV treatment and cure.

Key Words: Cost; Cost effectiveness; Economic analysis; Hepatitis C; Modelling; Shortened therapy; Sofosbuvir-ledipasvir; Treatment

\section{Une plus grande admissibilité à un traitement plus court de l'infection par l'hépatite $\mathrm{C}$ : les répercussions sur l'accès aux soins et les stratégies d'élimination au Canada}

HISTORIQUE : Toutes les associations antivirales orales à action directe
hautement efficaces, comme le sofosbuvir-lédipasvir, ont récemment été
homologuées au Canada, mais peuvent coûter jusquà $67000 \$$ pour un
cycle de 12 semaines, ce qui constitue un énorme obstacle économique à
des systèmes de santé qui sont surtout à payeur unique, comme celui de
l'Ontario. Chez les patients non cirrhotiques atteints du virus de l'hépatite C
(VHC) de génotype 1 ayant une charge virale de départ inférieure à
$6 \times 10^{6} \mathrm{UI} / \mathrm{mL}$, un traitement au sofosbuvir-lédipasvir peut être raccourci à
huit semaines sans compromettre une efficacité de $95 \%$ ou plus. On ne sait
pas combien de patients de l'Ontario infectés par le VHC sont admissibles
à ce type de traitement ni les économies qui s'y rapportent. Les auteurs
stipulent qu'un traitement plus court par patient, indépendamment de la
charge virale de départ, entraînerait des économies considérables pour la
santé publique et une efficacité accessoire, ce qui accroît la capacité théra-
peutique et la guérison du VHC. pétict et la guérison du VHe.

le coût pour guérir un patient et les économies par patient en vertu de trois voies d'admissibilité : prudent, permissif et idéal. Dans le modèle prudent, chaque patient est traité pendant 12 semaines, indépendamment de sa charge virale de départ, tandis que dans le modèle permissif, les patients ayant une charge virale de départ inférieure à $6 \times 10^{6} \mathrm{UI} / \mathrm{mL}$ sont traités pendant huit semaines. Dans le modèle idéal, chaque patient est traité huit semaines, indépendamment de sa charge virale de départ. Les patients en rechute sont traités de nouveau pendant 12 semaines. Les données obtenues auprès du Laboratoire de santé publique de l'Ontario ont permis de valider le modèle et de produire des résultats.

RÉSULTATS : En Ontario, 75,34 \% des patients atteints du VHC de génotype 1 ayant une charge virale de base inférieure à $6 \times 10^{6} \mathrm{UI} / \mathrm{mL}$ étaient admissibles à un traitement plus court. Dans un modèle idéal, le coût pour guérir un patient s'élevait à 47 328,44 \$, soit une réduction de 29 \% du coût du traitement curatif et une réduction du traitement de 3,5 semaines par rapport au modèle prudent. Le modèle idéal produisait des économies par patient de 3855,17 \$ (réduction de $8 \%$ du coût du traitement) et raccourcissait le traitement de 0,7 semaine par rapport au modèle permissif. C'était le plus court et le plus efficace, et il maintenait un taux de guérison de $95 \%$ ou plus.

CONCLUSIONS : Ces résultats démontrent que les recommandations en vue d'un cycle de traitement plus court de huit semaines au moyen d'antiviraux à action directe par voie orale chez des patients non cirrhotiques atteints du VHC de génotype 1, indépendamment de leur charge virale de départ, permettent à la santé publique de réaliser d'importantes économies et, en population, d'accroître le taux de traitement et de guérison du VHC.

four million incident cases annually, corresponding to a mean seroprevalence of approximately $3 \%(4,5)$. In Canada, the prevalence of HCV infection is unknown; the Public Health Agency of Canada has reported that approximately $1 \%$ of the population was anti-HCV

${ }^{1}$ William Osler Health System, Brampton Civic Hospital, Brampton; ${ }^{2}$ Division of Infectious Diseases, Department of Medicine, McMaster University,

Hamilton, Ontario

Correspondence: Dr Sergio M Borgia, William Osler Health System, 2100 Bovaird Street East, Brampton, Ontario L6R 3J7.

Telephone 905-494-2120 ext 57658, e-mail sergio.borgia@williamoslerhs.ca

Received for publication January 27, 2015. Accepted March 6, 2015 
positive in 2011 , of which approximately $0.75 \%$ would be expected to be viremic (6).

The burden of HCV in Canada is increasing based on previous modelling studies; however, the precise magnitude of this increase has not been well characterized $(7,8)$. Recent studies have attempted to refine the future burden of HCV disease in Canada and suggest that between now and 2035, cases of compensated and decompensated cirrhosis are expected to peak in 2031 at 36,210 and 3380 cases, respectively (9). Compared with 2013, cases of compensated cirrhosis, decompensated cirrhosis, hepatocellular carcinoma and liver-related deaths are expected to increase $89 \%, 80 \%, 205 \%$ and $160 \%$, respectively, by 2035 (9). In Ontario, HCV infection is associated with the greatest years of life lost due to premature mortality and health-adjusted life years more than any other infectious disease (10).

Previously, the treatment of chronic HCV required prolonged courses of pegylated interferon-alfa in combination with ribavirin for 24 to 48 weeks, and offered cure rates as measured by a sustained virological response (SVR) of approximately $40 \%$ to $50 \%$ (11). For HCV genotype 1 infections, the development of 'first-generation' directacting antiviral agents (DAAs) represented a major advancement in SVR rates - from $60 \%$ to $75 \%$ - depending on the combination of pre-existing viral and host prognostic factors (12-17). Very recently, the treatment of HCV infection has again witnessed enormous improvement, with SVR rates $>95 \%$ in uncomplicated patients using all-oral DAA combinations such as sofosbuvir-ledipasvir (SOF-LDV), simeprevir plus sofosbuvir, and ombitasvir/paritaprevir/r plus dasabuvir \pm ribavirin (18-23). The currently available all-oral HCV therapies achieve nearly all of the necessary conditions for a positive societal impact with regard to burden of HCV disease including shorter, safer, easier and more effective treatment, with no demonstrable clinical concerns of viral resistance or adverse side effects.

The improvement in curative therapy for the majority of $\mathrm{HCV}$ patients in Canada will have a transformative effect on the way these patients receive liver-related care, and has outpaced the ability of the Canadian health care system to effectively and quickly respond to the challenge of treating the increased number of patients required to make a meaningful impact on prevention, treatment delay and the future burden of HCV disease. Still, the number of individuals with $\mathrm{HCV}$ infection treated in Canada has remained relatively fixed at approximately 5000 patients per year (9).

\section{Rationale}

New therapies, such as SOF-LDV, are expensive $(\$ 67,000$ for a 12-week course) for governments and prohibitive for private-paying patients. Hence, under the fiscal constraints of a predominantly singlepayer health care system, such as that found in Canada, the most significant barrier to HCV treatment has become access to funding for curative therapy across a broad spectrum of patients. Although presently under funding review by provincial ministries of health, there are no current access options for these latest and most effective all-oral HCV treatments for the vast majority of treatment-eligible patients who lack private or third-party insurance.

The ability to shorten HCV therapy confers significant benefit to individual patients and to the overall impact on the capacity of a health care system challenged by suboptimal infrastructure and cost-containment concerns. Preliminary data suggest that six weeks of therapy may be the duration limit $(24,25)$. Recent pivotal trials have demonstrated that daily therapy with SOF-LDV for 12 weeks achieves a very high cure rate (95\%), with an exceedingly low $1 \%$ relapse rate as measured by SVR in noncirrhotic patients with HCV genotype 1 infection (20).

These same studies demonstrated that for the majority of patients with a baseline HCV RNA level $<6.0 \times 10^{6}(<6 \mathrm{M}) \mathrm{IU} / \mathrm{mL}$ treatment may be shortened to eight weeks without compromising SVR efficacy and with only minimal increases in the relapse rate. The registration trial that led to these recommendations examined relapse rates across a wide range of baseline viral loads; relapse rates were not appreciably impacted up to and including a baseline viral load of $10 \mathrm{M} \mathrm{IU} / \mathrm{mL}$. The
$6 \mathrm{M} \mathrm{IU} / \mathrm{mL}$ threshold of offering shortened treatment confers a very conservative relapse safety margin $(20,26)$.

Retreatment using SOF-LDV, or other all-oral DAA combinations, for 12 weeks in the few patients who relapse after eight weeks of therapy may be expected to achieve very high SVR rates given that patients who have previously failed a sofosbuvir regimen have been universally successfully retreated with a 12 -week regimen of SOF-LDV, although this remains to be confirmed (27).

These findings suggest a positive impact on the number of patients in Ontario living with HCV infection who may be cured using a shorter duration of therapy. Presently, the number, or proportion, of patients in Ontario that would benefit from a reduction in treatment duration remains unknown.

\section{Objectives}

The present investigation sought to quantify the number of individuals in Ontario with HCV genotype 1 infection who may benefit from a shorter duration of therapy based on their pretreatment baseline viral load. Data were obtained from databases of the Public Health Ontario Laboratory (PHOL). These data were used to construct and test a mathematical model of cost efficiency based on the discounted cost of shorter therapy ('the model'). Given the very few number of people who fail to achieve an SVR after treatment duration of either eight or 12 weeks, a more liberal recommendation to treat all noncirrhotic patients, regardless of baseline HCV viral load, with the shorter eightweek regimen suggests a simpler and viable cost-effective strategy. The authors suggest that offering a 12-week retreatment course to relapsed patients is both fair and ethical. Thus, based on population estimates of the number of individuals infected with HCV who fall above and below the $6 \mathrm{M} \mathrm{IU} / \mathrm{mL}$ threshold, the present hypothesis recommending a short, eight-week treatment course in every noncirrhotic HCV genotype 1 -infected patient, regardless of baseline viral load, would be expected to produce significant cost savings as predicted in the model. This recommendation has implications to increase treatment capacity and shorten the time horizon required to ensure a robust population impact on the advancement of liver health, prevent liver-related complications and, ultimately, contribute to the achievement of an elimination strategy for HCV infection in Ontario over the next 20 years and beyond.

\section{METHODS}

The present cost and cost savings exploratory analysis was based on specific input values from a previous study (26). Table 1 contains the input data used in the generation of the model. Some assumptions were made and used in the model structure, namely those contained in the information provided by an exploratory analysis of 500 patients in a community HCV database that revealed $80 \%$ of HCV genotype 1 patients had a baseline viral load of $<6 \mathrm{M} \mathrm{IU} / \mathrm{mL}$ (Borgia, data on file) and the baseline viral load values contained in the Ontario provincial dataset that approximately $75 \%$ of patients have a baseline viral load of $<6 \mathrm{M} \mathrm{IU} / \mathrm{mL}$ and approximately $25 \%$ of patients have a baseline viral load of $\geq 6 \mathrm{M} \mathrm{IU} / \mathrm{mL}$. This $75: 25$ ratio formed the basis of the present model. Also, the model assumed that either the population in question consists of patients without cirrhosis or that the presence of patients with cirrhosis does not alter the proportions of baseline viral loads, and that baseline HCV viral load is not correlated with the presence or absence of underlying cirrhosis (28). The model construct was developed using a spreadsheet (Excel 2010 version 14, Microsoft Corporation, USA). Three models and their rationale, were considered as follows:

1. Conservative model: Every patient is treated with LDV-SOF for 12 weeks regardless of baseline viral load. Physicians may choose to treat every patient with 12 weeks of therapy based on uncertainty of patients' true baseline viral loads between $1 \mathrm{M} \mathrm{IU} / \mathrm{mL}$ and $9 \mathrm{M} \mathrm{IU} / \mathrm{mL}$. Also, treating physicians may be hesitant to risk relapse with shortened therapy in cases in which they may foresee not having access to a retreatment course or particularly for noncirrhotic patients with stage 3 fibrosis. By applying the input values and 
TABLE 1

Input values used to generate models

\begin{tabular}{lcc}
\hline & \multicolumn{2}{c}{ Therapy, weeks } \\
\cline { 2 - 3 } Parameter & $\mathbf{1 2}$ & $\mathbf{8}$ \\
\hline Cure rate, $<6$ million $\mathrm{IU} / \mathrm{mL}$ at baseline & 96 & 97 \\
Cure rate, $\geq 6$ million $\mathrm{IU} / \mathrm{mL}$ at baseline & 94 & 90 \\
Relapse rate, $<6$ million $\mathrm{IU} / \mathrm{mL}$ at baseline & 2 & 2 \\
Relapse rate, $\geq 6$ million $\mathrm{IU} / \mathrm{mL}$ at baseline & 1 & 10 \\
Cost for therapy, $\$$ & 67,000 & \\
One-week therapy, $\$$ & 5583.33333 \\
\hline
\end{tabular}

Data presented as \% unless otherwise indicated. Cure and relapse rates from product monograph tables (HARVONI [ledipasvir/sofosbuvir, Gilead Sciences Inc, Canada])

assumptions, the curative cost per patient (CPP) for the conservative model can be calculated using the following formula:

$$
\mathrm{CPP}_{\text {conservative }}=12(x+y) * 5583.33333 /(x+y)
$$

in which $x$ and $y$ are the number of patients with viral load of $<6 \mathrm{M} \mathrm{IU} / \mathrm{mL}$ and $\geq 6 \mathrm{M} \mathrm{IU} / \mathrm{mL}$, respectively.

2. Permissive model: Patients are treated as per the LDV-SOF product monograph and Health Canada recommendations. Noncirrhotic $\mathrm{HCV}$-infected patients with a baseline viral load $\geq 6 \mathrm{M} \mathrm{IU} / \mathrm{mL}$ receive LDV-SOF for 12 weeks whereas noncirrhotic patients with $<6 \mathrm{M} \mathrm{IU} / \mathrm{mL}$ receive eight weeks of therapy. Only relapsed patients who received eight weeks of therapy are retreated. By applying the input values and assumptions, the curative CPP for the permissive model can be calculated using the following formula:

$$
\mathrm{CPP}_{\text {permissive }}=\left([8.24 x+12 y]^{* 5583.33333) /(x+y)}\right.
$$

3. Ideal model: All noncirrhotic patients are treated with LDV-SOF for eight weeks with all relapsed patients retreated for an additional 12 weeks of therapy. By applying the input values and assumptions, the curative CPP for the ideal model can be calculated using the following formula:

$$
\mathrm{CPP}_{\text {ideal }}=([8.24 x+9.2 y] * 5583.33333) /(x+y)
$$

It is expected that changes in the treatment duration would have an impact on the overall cost of curative therapy for $\mathrm{HCV}$ patients. To evaluate the impact of changing the treatment duration, the CPP for the three models were compared. The main outcome of interest was to maximize the cost savings, using the shortest mean duration, while maintaining a cure rate $\geq 95 \%$. The cost savings estimate is used to determine the return on each of the models. The cost savings per patient (CSPP) between the conservative and the permissive model is estimated using the following formula:

$$
\mathrm{CSPP}_{\text {conservative/permissive }}=(3.76 \mathrm{x}) * 5583.33333 /(x+y)
$$

The CSPP between the conservative and the ideal model is estimated using the following formula:

$$
\mathrm{CSPP}_{\text {conservative/ideal }}=((3.76 x+2.8 y) * 5583.33333) /(x+y)
$$

The CSPP between the permissive and the ideal model is estimated using the following formula:

$$
\mathrm{CSPP}_{\text {permissive/ideal }}=2.8 y^{*} 5583.33333 /(x+y)
$$

Supplementary data and description of the model are provided in Appendix 1.

\section{RESULTS}

To test the model, an analysis was performed using the Ontario patientlevel data from the PHOL datasets for patients falling above and below the $6 \mathrm{M} \mathrm{IU} / \mathrm{mL}$ thresholds for shortened therapy. The source data
TABLE 2

Hepatitis $\mathrm{C}$ virus (HCV) genoptype 1 patients according to viral load and sex

\begin{tabular}{lcccc}
\hline & \multicolumn{3}{c}{ Sex } & \\
\cline { 2 - 4 } HCV viral load & Female & Male & Not reported & Total \\
\hline$<6$ million IU/mL & 2746 & 5088 & 308 & 8142 \\
& $(79.18)$ & $(73.30)$ & $(77.39)$ & $(75.34)$ \\
$\geq 6$ million IU/mL & 722 & 1853 & 90 & 2665 \\
& $(20.82)$ & $(26.70)$ & $(22.61)$ & $(24.66)$ \\
Total & 3468 & 6941 & 398 & 10807 \\
& $(100.00)$ & $(100.00)$ & $(100.00)$ & $(100.00)$ \\
\hline
\end{tabular}

Data presented as $n$ (\%). Public Health Ontario Laboratory HCV type 1 viral load dataset April 26, 2010 to November 7, 2014

\section{TABLE 3}

\section{Output values for models}

\begin{tabular}{lcc}
\hline \multirow{2}{*}{ Output } & \multicolumn{2}{c}{ Value } \\
\cline { 2 - 3 } Curative cost per patient, conservative & $67,000.00$ & Weeks \\
Curative cost per patient, permissive & $51,183.61$ & 12 \\
Curative cost per patient, ideal & $47,328.44$ & 8.5 \\
Cost savings per patient, conservative/permissive & $15,816.39$ & 2.8 \\
Cost savings per patient, conservative/ideal & $19,671.56$ & 3.5 \\
Cost savings per patient, permissive/ideal & $3,855.17$ & 0.7 \\
\hline
\end{tabular}

provided by PHOL consists primarily of two data sources: an HCV viral load dataset and an HCV genotype dataset. The information stored in the PHOL discrete datasets includes duplicate data for patient identification characteristics, sex, and all available viral loads including non-genotype 1 and mixed genotype infections as measured by the COBAS TaqMan HCV Test, v2.0 assay (Roche Molecular Systems, USA). Clinical information is not collected and was not considered in this analysis. The two datasets were combined and linked to produce a total of 49,123 unique patients, of whom 10,807 were infected with HCV genotype 1 and were genotyped between April 26, 2010 and November 7, 2014. Further analysis revealed that 8142 genotype 1 patients $(75.34 \%)$ had a viral load of $<6 \mathrm{M} \mathrm{IU} / \mathrm{mL}$ and 2665 genotype 1 patients (24.66\%) had a viral load of $\geq 6 \mathrm{M} \mathrm{IU} / \mathrm{mL}$ (29). Table 2 provides information on some characteristics of patients in the Ontario patientlevel datasets.

For the conservative model, the CPP remained unchanged $(\$ 67,000)$. For the permissive model, the CPP was $\$ 51,183.61$, representing a $24 \%$ reduction in overall cost of therapy for $\mathrm{HCV}$ patients compared with the conservative model. The permissive model reduced the therapy duration by 2.8 weeks compared with the conservative model. Under the ideal model, the CPP was $\$ 47,328.44$, representing a $29 \%$ reduction in the overall cost of therapy for HCV patients and 3.5 weeks of shortened treatment duration compared with the conservative model. The ideal model generated a cost savings per patient of $\$ 3,855.17$ compared with the permissive model and an $8 \%$ reduction in the cost of treatment over the permissive model. For every $\$ 1.00$ spent on the ideal model, $\$ 1.08$ will be spent on the permissive model and $\$ 1.42$ will be spent on the conservative model. The ideal model is the most economically efficient of the three models and also offers the shortest mean treatment duration, while still maintaining a cure rate $\geq 95 \%$. The magnitude of the effectiveness of the ideal model over the permissive model can be expressed by stating that one additional patient can be cured for approximately every $13 \mathrm{HCV}$ patients treated. In a health care system with a fixed budget for HCV treatment, the ideal model would allow for more HCV patients to be treated. Table 3 summarizes the outputs from the three models using genotype 1 patients in Ontario. 


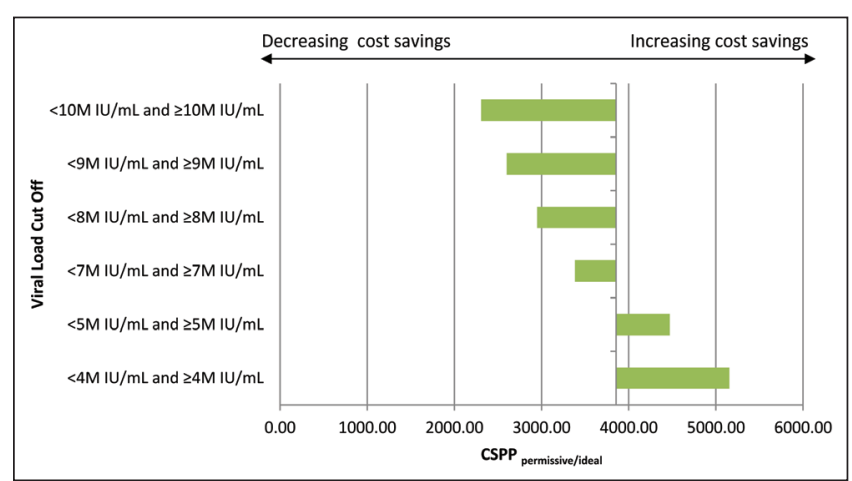

Figure 1) Cost savings per patient (CSPP) permissive/ideal with different hepatitis $\mathrm{C}$ virus viral load cut-offs

\section{Sensitivity analysis}

Based on data indicating that shortened therapy with SOF-LDV for eight weeks is equally effective as 12 weeks for baseline viral load thresholds up to $10 \mathrm{M} \mathrm{IU} / \mathrm{mL}$, a sensitivity analysis was conducted to determine how changes in the baseline viral load threshold to offer

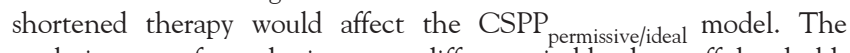
analysis was performed using seven different viral load cut-off thresholds provided in the PHOL patient-level dataset. Baseline viral load cut-offs in $1 \mathrm{M} \mathrm{IU} / \mathrm{mL}$ increments ranging between $4 \mathrm{M} \mathrm{IU} / \mathrm{mL}$ to $10 \mathrm{M} \mathrm{IU} / \mathrm{mL}$ were considered.

Changes in the CSPP viral load cut-off of $4 \mathrm{M} \mathrm{IU} / \mathrm{mL}$ to $\$ 2,307.32$ for a viral load cut-off of $10 \mathrm{M} \mathrm{IU} / \mathrm{mL}$. Overall, there are cost savings irrespective of the viral

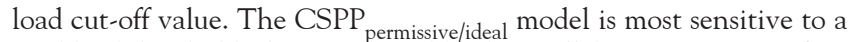
viral load threshold of $10 \mathrm{M}$; all viral load cut-offs between $10 \mathrm{M} \mathrm{IU} / \mathrm{mL}$ and $6 \mathrm{M} \mathrm{IU} / \mathrm{mL}$ had lesser effects on the CSPP permissive/ideal $_{\text {model. }}$ Viral load thresholds between $4 \mathrm{M} \mathrm{IU} / \mathrm{mL}$ and $6 \mathrm{M} \mathrm{IU} / \mathrm{mL}$ result in increased cost savings on CSPP ${ }_{\text {permissive/ideal, }}$ as shown in Figure 1.

\section{DISCUSSION}

The results of the present modelling analysis demonstrate a significant gain in efficiency in both cost and time to cure patients chronically infected with HCV in Ontario, and offers substantial collateral advantages. Compared with the permissive model, our ideal model saves $\$ 3,855.17$ per patient and shortens therapy by 0.7 weeks per patient. Of the estimated 5000 patients treated yearly in Canada, not all of whom achieve an SVR on older therapy, these savings represent an additional 3500 treatment weeks that would accommodate 412 additional patients yearly who could be not just treated, but almost all cured. It should not escape notice that, in addition to medication cost savings, there would be significant additional savings found in hospital, laboratory, nursing and physician costs that contribute to overall cost burden.

Presently, aside from SOF-LDV, there are no other all-oral treatment options that allow for treatment duration $<12$ weeks in patients with HCV genotype 1 infection; thus, any prorated discounts of other all-oral genotype 1 regimens are not possible at this time.

On a broader population level, shortening therapy for all genotype 1 noncirrhotic HCV patients to eight weeks with SOF-LDV will enable more patients to be integrated into HCV treatment opportunities over time. The estimated 251,990 HCV viremic patients in Canada represent a viable reservoir in whom to target the efficiencies predicted by our model using a shorter eight-week course of therapy. Other provinces deliberating funding criteria for $\mathrm{HCV}$ treatment may benefit from similar modelling analyses.

There are some limitations associated with our model. First, the model hypothesis was based on a relatively small provincial community database of $500 \mathrm{HCV}$ patients with an 80:20 ratio of genotype 1 patients with a baseline HCV viral load $<6 \mathrm{M} \mathrm{IU} / \mathrm{mL}$. Reassuringly, the number of unique genotype 1 patients with a viral load $<6 \mathrm{M} \mathrm{IU} / \mathrm{mL}$ (75.34\%) contained in the entire Ontario provincial database and used to test the model was very close to our community estimate. Nevertheless, the patient-level data contained in the PHOL datasets may not be fully representative of the Ontario HCV population due to missed linkage analysis, errors in patient coding information and unforeseen data entry errors. This model does not take into account the trivial incremental cost of the addition of ribavirin if necessary in patients requiring retreatment nor does it consider additional retreatment after a second relapse, however rare that necessity. Finally, the model is tied to the manufacturer's prenegotiated list price of $\$ 67,000$ for SOF-LDV (Harvoni, Gilead Sciences Inc, USA), which may not be the price that provincial governments ultimately pay for a course of curative therapy; however, the relative savings over total expenditures would be preserved and, in general, the model will afford savings regardless of the final price based on prorated discounts for shorter treatment durations. A recent analysis has shown that the cost of treatment per SVR, defined as the cost per regimen divided by the SVR rate of that regimen, is a valuable metric to frame discussions concerning access to treatment funding (30). In fact, the cost per SVR of $94 \%$ for a 12 -week course of therapy for SOF-LDV is approximately $\$ 71,277$ - significantly lower than the cost per SVR of previously funded treatments containing first-generation DAA agents in combination with interferon and ribavirin (30). However, we believe it useful to also examine retail drug costs because it aids in framing cost analyses such as ours. In an era in which the efficacy benchmark has been recalibrated and SVR rates are $>95 \%$, a drug's retail price and its 'cost per SVR' will be very similar. Our model builds on the 'cost per SVR' discussion and supports even greater efficiencies $\left(\$ 47,328.44 \mathrm{CPP}_{\text {ideal }}\right)$ by taking into account the shorter treatment duration and the specific relapse and retreatment costs.

These results demonstrate that recommendations for a shortened treatment course of eight weeks using all-oral DAAs in genotype-1 noncirrhotic HCV-infected patients, regardless of baseline viral load, confers significant public cost savings and, on a population level, offers opportunities for expanded HCV treatment and cure.

ACKNOWLEDGEMENTS: The authors thank Alex Marchand-Austin and Vica Dang at Public Health Ontario (PHOL) and Homie Razavi from the Center for Disease Analysis (CDA), Louisville, Colorado, USA.

DISCLOSURES: This study was supported by an unrestricted grant from Gilead Sciences Canada, manufacturers of antiviral therapies for HCV. The sponsor had no input into the design, conduct or analysis of this study, drafting of the manuscript, nor the decision to submit the manuscript for publication. Sergio Borgia has received research support, consulting, and/or speaking fees from Gilead Sciences, Merck Canada, Roche Canada, Vertex, Janssen, and Abbvie. Nike Rowaiye has no declared disclosures. Homie Razavi is an employee of the Centre for Disease Analysis and Alex Marchand-Austin and Vica Dang are employees of PHOL.

\section{APPENDIX 1: DERIVATION OF MODELS}

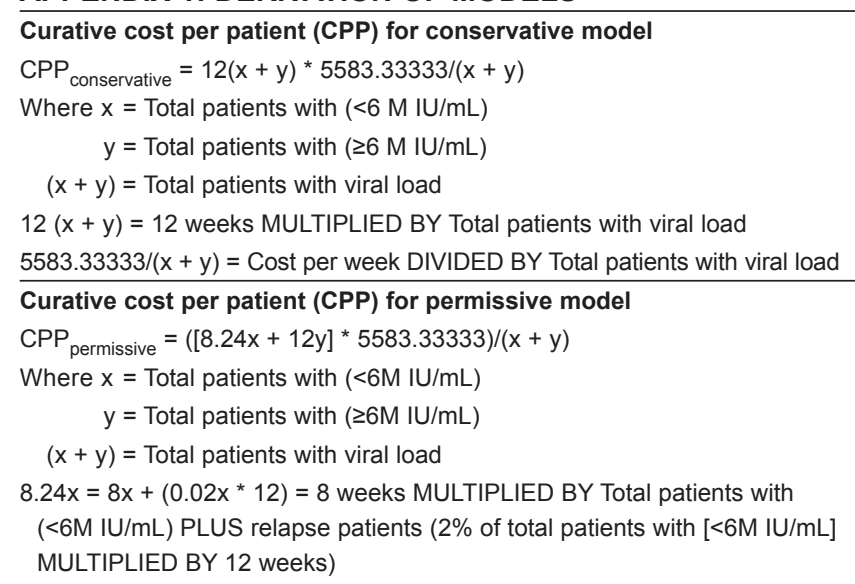

$12 y=12$ weeks MULTIPLIED BY Total patients with ( $\geq 6 \mathrm{M} \mathrm{IU} / \mathrm{mL})$

$5583.33333 /(x+y)=$ Cost per week DIVIDED BY Total patients with viral load 


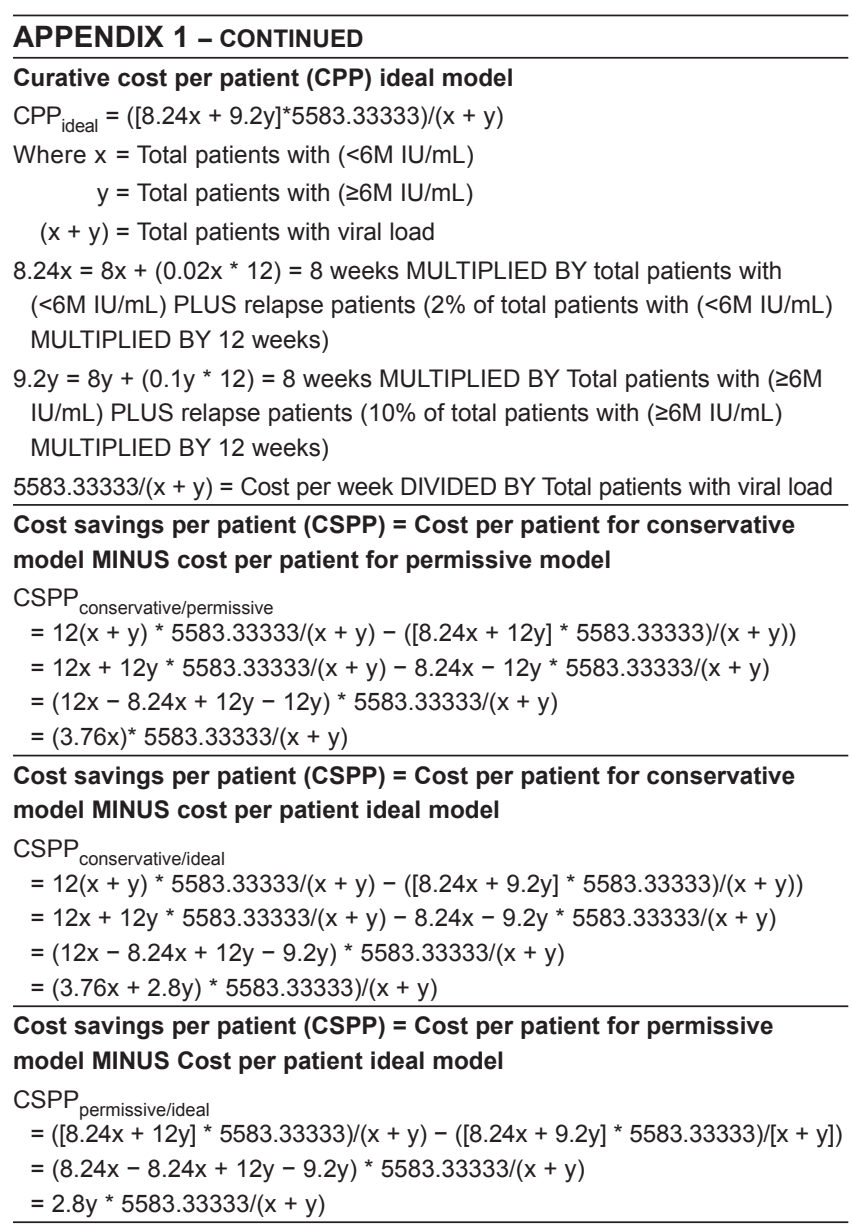

\section{REFERENCES}

1. Alberti A, Chemello L, Benvegnu L. Natural history of hepatitis C. J Hepatol 1999;31:17-24.

2. Koike K, Tsutsumi T, Miyoshi H, et al. Molecular basis for the synergy between alcohol and hepatitis $\mathrm{C}$ virus in hepatocarcinogenesis. J Gastroenterol Hepatol 2008;23:S87-91.

3. Perz JF, Armstrong GL, Farrington LA, et al. The contributions of hepatitis $\mathrm{B}$ and hepatitis $\mathrm{C}$ virus infection to cirrhosis and primary liver cancer worldwide. J Hepatol 2006;45:529-38.

4. Dore GJ, Ward J, Thursz M. Hepatitis C disease burden and strategies to mange the burden. J Viral Hepat 2014;21(Suppl 1):1-4.

5. Mohd Hanafiah K, Groeger J, Flaxman AD, Wiersma ST. Global epidemiology of hepatitis $\mathrm{C}$ virus infection: New estimates of age-specific antibody to HCV seroprevalence. Hepatology 2013;57:1333-42.

6. Trubnikov M. Developing estimates of prevalent and undiagnosed HCV infection in Canada in 2011. <www.youtube.com/watch?v=23 4ru9AFA6U\& list=PLy0zwf7_pKrXSh9bx6XxznPv65S44nN6q\&nor edirect=12014> (Accessed January 9, 2015).

7. Remis RS. Modelling the incidence and prevalence of hepatitis $\mathrm{C}$ infection and its sequelae in Canada, 2007: Final report. Community Acquired Infections Division, Centre for Communicable Diseases and Infection Control, Public Health Agency of Canada 2009. <http://epe.lac-bac.gc.ca/100/200/301/ phac-aspc/modeling hepatis_c_infection-e/HP40-39-2009E.pdf> (Accessed January 9, 2015)

8. Zou S, Tepper M, El Saadany S. Prediction of hepatitis C burden in Canada. Can J Gastroenterol 2000;14:575-80.
9. Myers RP, Krajden M, Bilodeau M, et al. Burden of disease and cost of chronic hepatitis C infection in Canada. Can J Gastroenterol Hepatol 2014;28:243-50.

10. Kwong JC, Crowcroft NS, Campitelli MA, et al. Ontario Burden of Infectious Disease Study (ONBOIDS): An OAHPP/ICES Report. Toronto: Ontario Agency for Health Protection and Promotion; Institute for Clinical Evaluative Sciences; 2010.

11. McHutchison JG, Lawitz EJ, Shiffman ML, et al. Peginterferon alfa-2b or alfa-2a with ribavirin for treatment of hepatitis $\mathrm{C}$ infection. N Engl J Med 2009;361:580-93.

12. Asselah T, Marcellin P. New direct-acting antivirals' combination for the treatment of chronic hepatitis C. Liver Int 2011;31(Suppl 1):68-77.

13. Jacobson IM, McHutchison JG, Dusheiko G, et al. Telaprevir for previously untreated chronic hepatitis $\mathrm{C}$ virus infection. N Engl J Med 2011;364:2405-16.

14. Poordad F, McCone J Jr, Bacon BR, et al. Boceprevir for untreated chronic HCV genotype 1 infection. N Engl J Med 2011;364:1195-206

15. Bacon BR, Gordon SC, Lawitz E, et al. Boceprevir for previously treated chronic HCV genotype 1 infection. N Engl J Med 2011;364:1207-17.

16. Zeuzem S, Andreone P, Pol S, et al. Telaprevir for retreatment of HCV infection. N Engl J Med 2011;364:2417-28.

17. Sherman KE, Flamm SL, Afdhal NH, et al. Response-guided telaprevir combination treatment for hepatitis $\mathrm{C}$ virus infection. N Engl J Med 2011;365:1014-24.

18. Afdal N, Zeuzem S, Kwo P, et al. Ledipasvir and sofosbuvir for untreated HCV genotype 1 infection. N Engl J Med 2014;370:1889-98.

19. Afdal N, Reddy KR, Nelson DR et al. Ledipasvir and sofosbuvir for previously treated HCV genotype 1 infection. N Engl J Med 2014;370:1483-93.

20. Kowdley K, Gordon S, Reddy KR, et al. Ledipasvir and sofosbuvir for 8 or 12 weeks for chronic HCV without cirrhosis. N Engl J Med 2014;370:1879-88

21. Feld JJ, Kowdley KV, Coakley E, et al. Treatment of HCV with ABT-450/r-ombitasvir and dasabuvir with ribavirin. N Engl J Med 2014;370:1594-603.

22. Zeuzem S, Jacobson IM, Baykal T, et al. Retreatment of HCV with ABT-450/r-ombitasvir and dasabuvir with ribavirin. N Engl J Med 2014:370:1604-14

23. Poordad F, Hezode C, Trinh R, et al. ABT-450/r-ombitasvir and dasabuvir with ribavirin for hepatitis $\mathrm{C}$ with cirrhosis. N Engl J Med 2014;370:1973-82.

24. Lawitz E, Poordad F, Gutierrez JA, et al. C-SWIFT: Grazoprevir (MK$5172)+$ elbasvir (MK-8742) + sofosbuvir in treatment-naive patients with hepatitis $\mathrm{C}$ virus genotype 1 infection, with and without cirrhosis, for durations of 4, 6, or 8 weeks. Abstract 33 . The 65th Annual Meeting of the American Association for the Study of Liver Diseases (AASLD). Boston, November 7 to 11, 2014.

25. Kohli A, Osinusi A, Sims Z, et al. Virological response after 6 week triple-drug regimens for hepatitis C: A proof-of-concept phase 2A cohort study. Lancet 2015 January 12 (Epub ahead of print).

26. HARVONI ${ }^{\mathrm{TM}}$, Gilead Sciences Inc. Foster City, CA Dated October 14, 2012 [product monograph]. <http://www.gilead.ca/pdf/ca/ harvoni_pm_english.pdf> (Accessed November 17, 2015).

27. Wyles DL, Pockros PJ, Yang JC, et al. Retreatment of patients who failed prior sofosbuvir-based regimens with all oral fixed-dose combination ledipasvir/sofosbuvir plus ribavirin for 12 weeks. Abstract 235. The 65th Annual Meeting of the American Association for the Study of Liver Diseases (AASLD). Boston, November 7 to 11, 2014.

28. Zhu Y, Chen S. Antiviral treatment of hepatitis $\mathrm{C}$ virus infection and factors affecting efficacy. World J Gastroenterol 2013;19:8963-73.

29. Public Health Ontario Laboratories (PHOL). Examination of HCV Viral Load in Ontario Population. PHOL HCV Type 1 Viral Load dataset April 26, 2010 to November 7, 2014 [Data on file].

30. Shafran $S$. The hepatitis $C$ genotype paradox: Cost per treatment is increasing, but cost per cure is decreasing. Can J Gastroenterol Hepatol 2015;29:46-8. 


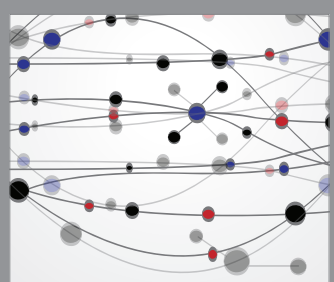

The Scientific World Journal
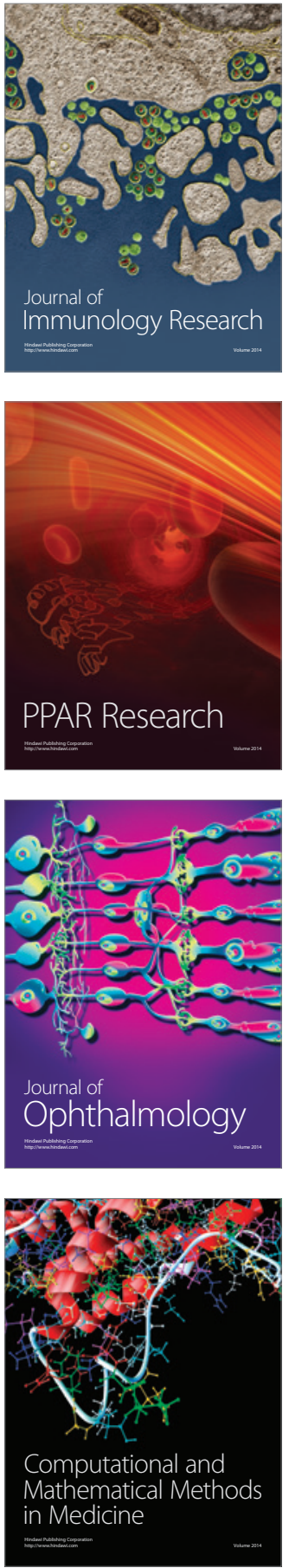

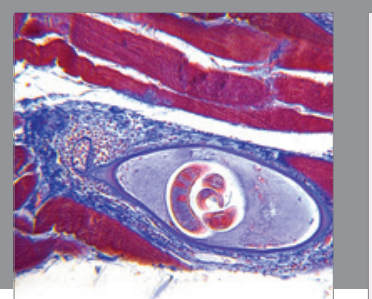

Gastroenterology Research and Practice

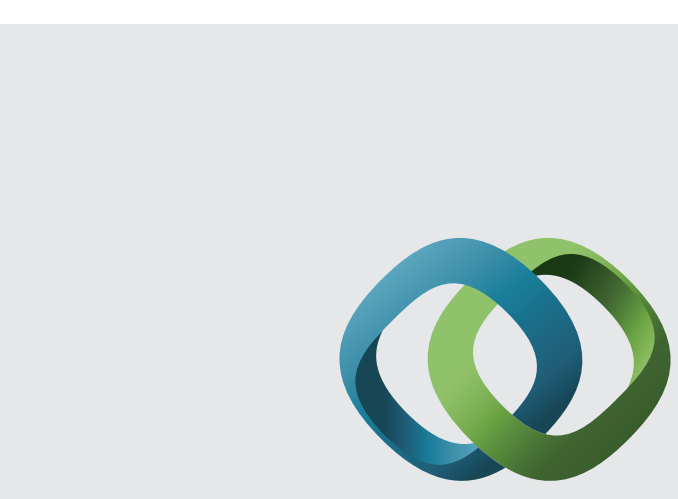

\section{Hindawi}

Submit your manuscripts at

http://www.hindawi.com
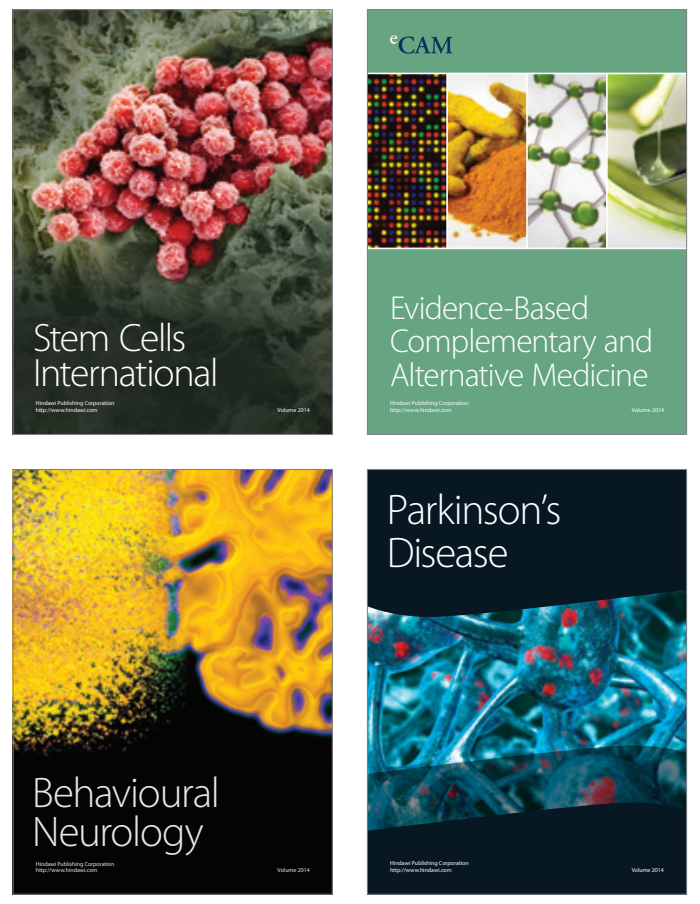
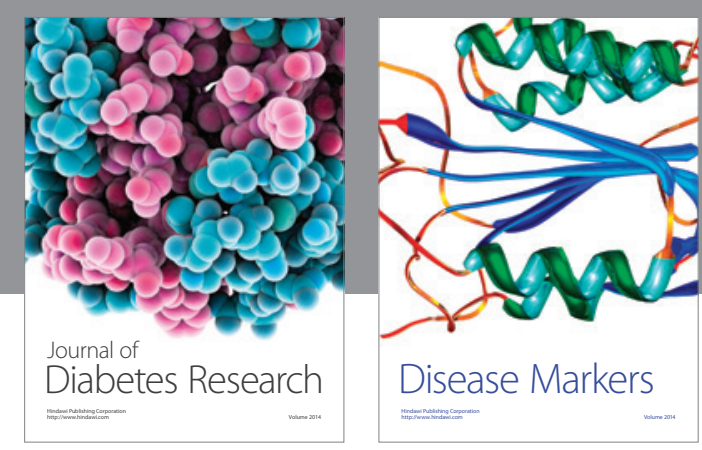

Disease Markers
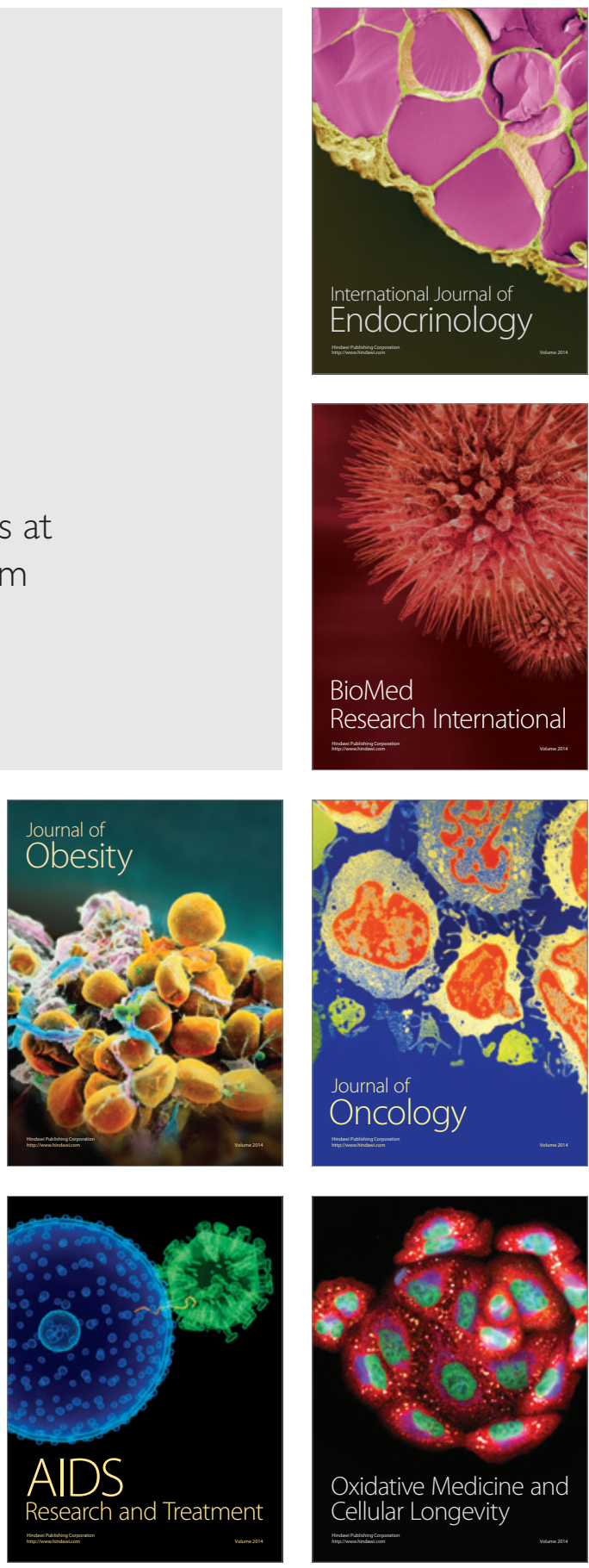